\title{
KOMPETENSI DIGITAL SEBAGAI STRATEGI PENINGKATAN PENDIDIKAN TINGGI DI ERA MODERN
}

(Studi Deskriptif pada Sekolah Tinggi Agama Buddha Negeri Sriwijaya Tangerang Banten)

\author{
Heriyanto \\ Sekolah Tinggi Agama Buddha Negeri Sriwijaya Tangerang Banten \\ heriyanto@stabn-sriwijaya.ac.id
}

Permasalahan dalam kajian ini adalah bagaimana sebuah kompetensi digital ditumbuhkan dalam lingkungan akademik perguruan tinggi khususnya STABN Sriwijaya sehingga menjadi sebuah strategi dan langkah-langkah strategis guna peningkatan proses pendidikan yang dilakukan. Penjabaran data kualitatif permasalahan dalam pemanfaatan teknologi digital mahasiswa, dosen, dan tenaga kependidikan dalam proses mendapatkan informasi, mengevaluasi informasi, menciptakan dan meyebarkan knowledge baru memberikan gambaran kompetensi yang dibutuhkan guna keluar dari permasalahan yang ada.

Kajian ini merupakan kajian kualitatif dengan pendekatan deskriptif. Objek kajian adalah keterampilan dan kemampuan digital Sivitas Akademika yang terlibat dalam operasional akademik STABN Sriwijaya, dengan subjek yang meliputi mahasiswa, dosen, dan tenaga kependidikan STABN Sriwijaya. Data dalam kajian ini berupa data kualitatif yang didapatkan dari sumber primer dan skunder. Analisis data dengan menggunakan model analisis Miles and Huberman. Metode pengumpulan data dengan observasi, wawancara, dan dokumentasi.

Hasil kajian menjelaskan kompetensi digital mejadi solusi dan strategi dalam mengatasi berbagai permasalahan yang ada pada perguruan tinggi khususnya dalam menghadapi era pendidikan modern. Kompetensi Knowledge Assembly, Etika Komputer, Internet Searching, Content Evaluation, Knowledge Assembly, Manajement Data, Security Computer, Backup Data, Hypertextual Navigation, dan Maintenance Computer merupakan sebuah keharusan yang menjadi penting terhadap operasinal pendidikan. Mahasiswa, dosen, dan tenaga kependidikan diharapakkan mencapai dan memiliki kompetensi digital untuk keluar dari permasalahan yang ada, lebih lanjut akan memberikan kontribusi besar terhadap tercapainya tujuan pendidikan yang telah ditetapkan. Impelemntasi kompetensi digital membutuhkan langkah-langkah strategis dan perencanaan yang baik sehinga dapat terwujud dan memberikan kontribus maksimal terhadap peningkatan pendidikan di era modern. Model, strategi, dan pendekatan pembelajaran salah satu bentuk strategi impelemtasi kompetensi digital pada mahasiswa. Sedangkan untuk dosen dan tenaga kependidikan, langkah strategis implementasi kompetensi digital dapat dilakukan melalui seminar, pelatihan, Focus Group Discussion (FGD), dan berbgai kegiatan knowledge sharing.

Kompetensi Digital, Pendidikan Tinggi, Strategi Pembelajaran 


\section{A. PENDAHULUAN}

\section{Latar Belakang, Permasalahan, dan Tujuan}

Pergeseran paradigma pendidikan membawa dampak dan perubahan besar terhadap proses pendidikan itu sendiri. Sebagai sebuah institusi pendidikan tinggi, perguruan tinggi harus terus berbenah untuk menjalankan berbagai tanggungjawab dan dimensi yang melekat. Pendidikan tinggi merupakan gerbang utama pencetak insan intelektual menjadi basis utama pendidikan tinggi, penemuan, dan berbagai riset baru yang dilakukan dengan cara-cara ilmiah. Dimensi keilmuan adalah bagaimana sebuah perguruan tinggi terus menciptakan insan-insan intelektual dengan berbagai kompetensi dan knowledge yang dimiliki guna selaras dengan perkembangan masyarakat dan kemajuan era moderenisasi.

Modernisasi dengan perkembangan sistem dan teknologi informasi tidak semata berkontribusi positif. Berbagai permasalahan dan dampak negatif sporadis bermunculan, tidak terkecuali pada lingkungan akademik perguruan tinggi. Plagiarisme, pelanggaran hak kekayaan intelektual, berita tidak benar dan menyesatkan, akses konten ilegal, serta prilaku berjejaring sosial yang buruk menjadi permasalahan yang juga muncul pada lingkungan akademik perguruan tinggi.

Ciri-ciri abad 21 dengan model pembelajarannya adalah mendorong pesera didik mencari tahu dari berbagai sumber, begitu juga dengan mahasiswa dalam proses pendidikan pada sebuah perguruan tinggi. Berbagai kegiatan dan kebutuhan akademik untuk mengumpulkan, menyiapkan, menyimpan, memproses, mengumumkan, menganalisis, dan menyebarkan informasi tidak pernah lepas dari peran sistem dan teknologi informasi. Teknologi digital menjadi sebuah alat bukan sekadar support melainkan sebuah keharusan dalam memenuhi berbagai kebutuhan informasi akademik. Kenyataan yang ada, perkembangan sistem informasi dan teknologi digital tidak disambut dengan kompetensi literasi yang memadai, skills sistem informasi dan teknologi digital belum terimplementasi pada Sivitas Akademika perguruan tinggi, serta urgensi 
kompetensi digital yang tidak ditindaklanjuti dengan sebuah manajemen dan kebijakan yang strategis.

Era kompetensi global dan pendidikan modern mengharuskan peningkatan knowledge yang membutuhakan dukungan penerapan media dan berbagai teknologi digital. Information media and technology skills menjadi sebuah keharusan bagaimana civitas akademik memiliki keterampilan teknologi dan media informasi. Keterampilan teknologi dan media informasi diturunkan menjadi sebuah kemampuaan literasi dalam pemanfaatan media digital, media informasi, dan media ICT, menjadi satu-kesatuan dalam keterampilan digital. Kompetensi digital menjadi penting untuk bagaimana memanfaatkan teknologi sebagai alat memenuhi kebutuhan akademik sivitas perguruan tinggi, literasi informasi, dan menciptakan knowledge baru melalui interaksi dengan teknologi.

Sekolah Tinggi Agama Buddha Negeri Sriwijaya Tangerang Banten (STABN Sriwijaya) merupakan Perguruan Tinggi Keagamaan Buddha yang juga menghadapi permasalahan yang sama. Kenyataan yang ada, sistem dan teknologi digital tidak disambut baik dengan kemampuan dan keterampilan yang memadai. Rendahnya kemampuan penggunaan mesin pencari internet danlam mengkases informasi, pemahaman yang kurang terhadap karakteristik website dan internet, kurang memahami tampilan dan halaman website, kurangnya kemampuan membuktikan kebenaran berita yang beredar di internet dan media sosial, serta rendanya kemampuan menyusun knowledge baru dengan informasi yang didapatkan melalui internet dan teknologi digital. Lebih spesifik permasalhan pada mahasiswa adalah kesulitan mendapatkan sumbersumber informasi akademik yang ilmiah dan kredibel, budaya langsung mengambil informasi dari internet tanpa mencantumkan nama pemilik dan alamat sumber, serta rendahnya keinginan membuat pengetauan baru dari berbagai informasi yang didapatkan dari internet.

Menjadi permasalahan tersendiri dalam penelitian ini adalah bagaimana sebuah kompetensi digital ditumbuhkan dalam lingkungan akademik perguruan tinggi 
khususnya STABN Sriwijaya sehingga menjadi sebuah strategi dan langkahlangkah strategis guna peningkatan proses pendidikan yang dilakukan. Penjabaran data kualitatif permasalahan dalam pemanfaatan teknologi digital mahasiswa, dosen, dan tenaga kependidikan dalam proses mendapatkan informasi, mengevaluasi informasi, menciptakan dan meyebarkan knowledge baru memberikan gambaran kompetensi yang dibutuhkan guna keluar dari permasalahan yang ada. Selanjunya hasil analisis menjadi sebuah kajian dalam bentuk perencanaan dan langkah-langkah strategis STABN Sriwijaya guna peningkatan proses pendidikan yang dilakukan.

\section{Manfaat Penelitian}

Hasil kajian dalam bentuk teori memberikan sumbangsih pengetahuan dalam bentuk teori khususnya berkaitan dengan kompetensi digital mahasiswa dan Sivitas Akademika dalam memenuhi kebutuhan informasi akademik yang mendukung operasional perguruan tinggi. Dari segi praktis, hasil kajian menjadi dasar dalam menentukan kebijakan dan langkah-langkah strategis guna peningkatan proses pendidikan di STABN Sriwijaya. Hasil kajian juga memberikan masukan bagi mahasiswa, dosen, tenaga kependidikan untuk melakukan berbagai kegiatan guna meningkatkan kompetensi digital yang dapat terimpelemnetasi secara nyata terhadap pada proses pendidikan di perguruan tinggi. Kontribusi terhadap pembelajaran, hasil kajian menjadi dasar pengembangan proses pembelajaran oleh dosen khusunya dalam menentukan materi dan strategi yang tepat untuk menciptakan berbagai kompetensi digital yang tergabung ke dalam knowledge mahasiswa.

\section{Tinjauan Pustaka}

Dalam Undang-undang Republik Indonesia Nomor 12 Tahun 2012 Tentang Pendidikan Tinggi, pendidikan tinggi adalah pendidikan pada jalur pendidikan sekolah pada jenjang yang lebih tinggi daripada pendidikan menengah di jalur pendidikan sekolah, mecakup program diploma, sarjana, magister, doktor, profesi, serta program dprsialisasi yang diselenggarakan oleh perguruan tinggi. 
Sedangkan perguruan tinggi adalah satuan pendidikan yang menyelenggarakan pendidikan tinggi (Indrajit dan Djokopranoto, 2004: 13).

Trend dunia abad 21 dan globalisasi memperlihatkan adanya revolusi di bidang penyelenggaraan pendidikan dengan kemajuan teknologi informasi dan komunikasi. Berbagai institusi pendidikan telah melakukan aktivitas perubahan dalam mengadopsi trend, perkembangan, dan kemajuan masyarakat yang terjadi. Paradigma dan perkembangan pendidikan modern merupakan adaptasi berbagai komponen bidang pendidikan untuk selalu meyesuaikan dengan perubahan dan tuntutan zaman yang ditunjukan dengan adanya perubahan sistem dan peradaban dalam kontek yang sangat luas. Fungsi dan perkembangan teknologi informasi dan komunikasi memberikan andil besar kebutuhan dalam bidang pendidikan yang harus dijawab untuk mempertahankan tingkat relevansi terhadap adanya perubahanperubahan dan peradaban masyarakat (Indrajit, 2011: 51-52). Kemajuan teknologi memasuki berbagai sendi kehidupan tidak terkecuali dalam pendidikan, membawa perubahan besar terhadap paradigma pembelajaran dan pola belajar. Untuk meghadapi pergeseran paradigma dan pola pembelajaran era modern, setiap individu harus memiliki ketermpilan berpikir kritis, pengetahuan dan literasi digital, literasi informasi, literasi media, dan menguasai teknologi informasi dan komunikasi (Frydenberg \& Andone, 2011).

Kompetensi digital menjadi sebuah indikator dan alat ukur kemampuan seseorang hingga dapat dikatakan memiliki kemampuan digital. Gilster (1997: 3) membagi kompetensi literasi digital (digital literacy competencies) ke dalam empat kompetensi inti yang perlu dimiliki seseorang sehingga dapat dikatakan memiliki kemampuan literasi digital (digital literacy), antara lain: Internet Searching, Hypertextual Navigation, Content Evaluation, Knowledge Assembly. Davis \& Shaw (2011) menyatakan terdapat 6 kompetensi utama digital literacy, meliputi: Pemahaman format digital dan non digital, Penciptaan dan 
komunikasi informasi digital, Evaluasi informasi, Penghimpunan atau perakitan pengetahuan, Literasi informasi, dan Literasi media.

\section{B. METODOLOGI}

Kajian ini merupakan kajian kualitatif dengan pendekatan deskriptif. Objek kajian adalah keterampilan dan kemampuan digital Sivitas Akademika yang terlibat dalam operasional akademik STABN Sriwijaya, dengan subjek yang meliputi mahasiswa, dosen, dan tenaga kependidikan STABN Sriwijaya. Data dalamkajian berupa data kualitatif yang didapatkan dari sumber primer dan skunder. Analisis data dengan menggunakan model analisis Miles and Huberman. Metode pengumpulan data dengan observasi, wawancara, dan dokumentasi.

Observasi menjadi metode pengumpulan data utama. Observasi dilakukan terhadap pembelajaran didalam kelas, khususnya dalam mata kuliah Komputer I, Komputer II, Media Pembelajaran, sertaTeknologi Informasi dan Komunikasi (TIK). Observasi terhadap dosen dilakukan melalui berbagai kegiatan operasional pada STABN Sriwijaya dan berbagai kendala dan permasalahan dosen berkaitan dengan pemanfaatan sistem dan teknologi digital.Observasi keterampialan dan kemampuan digital terhadap tenaga kependidikan berlangsung dalam berbagai kegiatan dalam menjalankan tugas dan fungsi yang memanfaatkan berbagai bentuk teknologi digital pada STABN Sriwijaya. Wawancara dilakukan pada beberapa mahasiswa yang dirasa memiliki keterampilan digital berbeda lebih baik dari mahasiswa lainnya. Pengumpulan data dalam bentuk dokumentasi dengan mengumpulkan berbagai dokumen yang bermanfaat dan memberikan sumbangsih data untuk kajian ini.

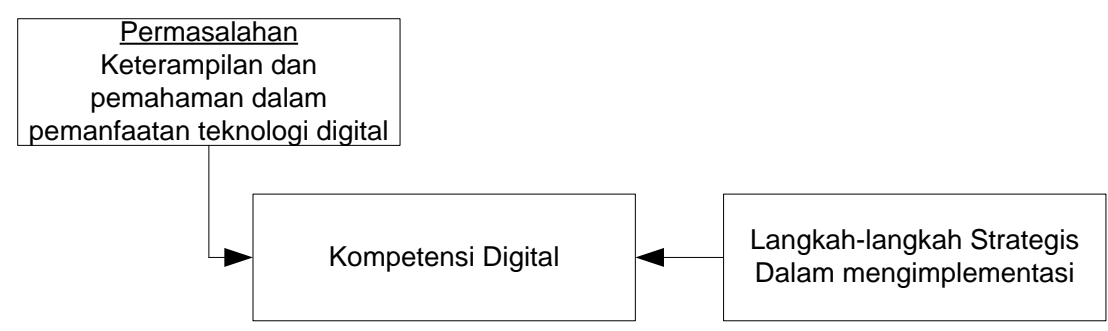

Gambar 1. Paradigma Kajian 


\section{HASIL DAN PEMBAHASAN}

Pemanfaatan sistem dan teknologi digital Sivitas Akademika STABN Sriwijaya terimplementasi pada kegiatan pembelajaran yang melibatkan dosen dan mahasiswa. Pelaksanaan tugas dan fungsi tenaga kependidikan dalam mendukung kegiatan akademik juga tidak lepas dari peran dan fungsi teknologi digital.

\section{Permasalahan mahasiswa, dosen, dan tenaga kependidikan dalam pemanfaatan teknologi digital}

Permasalahan dalam pemanfaatan teknologi digital mahasiswa, dosen, dan tenaga kependidikan dalam proses mendapatkan informasi, mengevaluasi informasi, menciptakan, dan meyebarkan knowledge meliputi berbagai aspek, dijabarkan dalam Tabel 1.

Tabel 1. Permasalahan mahasiswa, dosen, dan tenaga kependidikan dalam pemanfaatan teknologi digital

\begin{tabular}{|l|l|}
\hline Mahasiswa & $\begin{array}{l}\text { Copy Paste file digital dalam mendukung tugas } \\
\text { dan kebutuhan akademik lain tanpa melakukan } \\
\text { edit dan pengembangan. Tidak membuat } \\
\text { pengetauan baru dengan bahan informasi yang } \\
\text { didaptkan melalui file digital }\end{array}$ \\
\hline Penulisan Sumber, Referensi, dan Pustaka & $\begin{array}{l}\text { Tidak mencantumkan sumber pustaka dan } \\
\text { referensi yang didapatkan dari dokumen digital } \\
\text { orang lain melalui hasil pencarian di internet }\end{array}$ \\
\hline Pemahaman Search Engine Internet & $\begin{array}{l}\text { Kurangnya pemahaman penggunaan } \text { keyword } \\
\text { (kata kunci) dalam menggunakan search engine } \\
\text { internet }\end{array}$ \\
\hline Penggunaan Tools Website & $\begin{array}{l}\text { Ketidaktahuan dan kurangnya keinginan } \\
\text { penggunaan alat bantu yang ada pada website } \\
\text { seperti Frequently Asked Question (FAQ), alat } \\
\text { terjemah bahasa, dan Contact Us }\end{array}$ \\
\hline $\begin{array}{l}\text { Sumber-sumber kajian Buddhis yang } \\
\text { kredibel }\end{array}$ & $\begin{array}{l}\text { Kurangnya pengetahuan sumber-sumber } \\
\text { referensi, kajian, jurnal, dan website yang } \\
\text { kredibel, khususnya yang digunakan dalam } \\
\text { mendukung pembelajaran keagamaan Buddha. }\end{array}$ \\
\hline Manajemen Data dan File & $\begin{array}{l}\text { Penamaan file dan folder, meletakan lokasi data, } \\
\text { meyimpan data pada media penyimpanan }\end{array}$ \\
\hline Security data dan File & $\begin{array}{l}\text { Kemampuan menjaga data dari virus, worm, } \\
\text { dan malware }\end{array}$ \\
\hline Backup Data & $\begin{array}{l}\text { Kurangnya pembiasaan, pemahaman dan } \\
\text { keinginan melakukan backup data }\end{array}$ \\
\hline
\end{tabular}




\begin{tabular}{|c|c|}
\hline Dosen & \\
\hline Pemahaman Security Data dan File & $\begin{array}{l}\text { Kurangnya pemahaman dalam menjaga data dan } \\
\text { file, khususnya dari virus, worm, dan malware }\end{array}$ \\
\hline Budaya Sharing Knowledge & $\begin{array}{l}\text { Kurangnya keinginan untuk berbagi } \\
\text { pengetahuan dan pengalaman melalui blog dan } \\
\text { website }\end{array}$ \\
\hline Penulisan Sumber, Referensi, dan Pustaka & $\begin{array}{l}\text { Budaya copy paste tanpa mencantumkan } \\
\text { sumber, dan rendahnya analisi serta keinginan } \\
\text { membuat pengetahuan baru hasil interaksi } \\
\text { dengan teknologi digital }\end{array}$ \\
\hline Keterlibatan Forum Diskusi Ilmiah & $\begin{array}{l}\text { Kurangnya keterlibatan dosen dalam forum } \\
\text { diskusi ilmiah khususnya melalui media online }\end{array}$ \\
\hline Akses Jurnal Ilmiah dan Jurnal Buddhis & $\begin{array}{l}\text { Rendahnya akses terhadap website jurnal ilmiah } \\
\text { dan jurnal Buddhis, khususnya dengan } \\
\text { pemanfaatan media internet }\end{array}$ \\
\hline Maintenance dan Instal Software & $\begin{array}{l}\text { Belum dapat memperbaiki berbagai } \\
\text { permasalahan komputer, khususnya pada laptop } \\
\text { pribadi dan Personal Computer (PC) Kantor }\end{array}$ \\
\hline Penggunaan Tools Website & $\begin{array}{l}\text { Ketidaktahuan dan kurangnya keinginan } \\
\text { penggunaan alat bantu yang ada pada website } \\
\text { seperti Frequently Asked Question (FAQ), alat } \\
\text { terjemah bahasa, dan Contact Us. Kurangnya } \\
\text { pemahaman penggunaan website-website } \\
\text { tertentu untuk mendukung tugas dan fungsi } \\
\text { sebagai dosen }\end{array}$ \\
\hline \multicolumn{2}{|l|}{ Tenaga Kependidikan } \\
\hline Karakteristik Website dan Link & $\begin{array}{l}\text { Kurangnya pemahaman terhadap Karakteristik } \\
\text { Website dan fungsi link-link pada website }\end{array}$ \\
\hline Kapaistas File, Data, dan Bandwith & $\begin{array}{l}\text { Kurangnya pemahaman terhadap kapisitas File, } \\
\text { Data, dan Bandwith. Rendahnya pengetahuan } \\
\text { terhadap berbagai software yang berfungsi } \\
\text { untuk mengatasi berbagai permasalahan } \\
\text { kapaistas File, Data, dan Bandwith. }\end{array}$ \\
\hline $\begin{array}{l}\text { Penelusuran Informasi dan Struktur } \\
\text { Website }\end{array}$ & $\begin{array}{l}\text { Rendahnya keinginan untuk mempelajari dan } \\
\text { mencari informasi lebih dalam melalui website } \\
\text { dan internte }\end{array}$ \\
\hline Security Computer & $\begin{array}{l}\text { Kurangnya keterampilan untuk menjaga } \\
\text { komputer dan laptop agar tetap berfungsi } \\
\text { maksimal tanpa kendala. Kurangnya } \\
\text { pemahaman untuk menjaga data dan file digital }\end{array}$ \\
\hline Penggunaan Tools Website & $\begin{array}{l}\text { Ketidaktahuan dan kurangnya keinginan } \\
\text { penggunaan alat bantu yang ada pada website } \\
\text { seperti Frequently Asked Question (FAQ), alat } \\
\text { terjemah bahasa, dan Contact Us. }\end{array}$ \\
\hline Dukungan website dengan fungsi khusus & $\begin{array}{l}\text { Kurangnya pemahaman penggunaan website- } \\
\text { website dalam mengatasi permasalahan } \\
\text { berkaitan dengan tugas dan fungsi tenaga } \\
\text { kependidikan }\end{array}$ \\
\hline
\end{tabular}

Bentuk-bentuk permasalahan yang ada pada Tabel 1 berkaitan dengan keterampilan mahasiswa, dosen, dan tenaga kependidikan STABN Sriwijaya dalam pemanfaatan teknologi digital, dimana teknologi digital 
sudah tidak terpisahkan lagi yang merupakan enabler operasional pendidikan di era modern, khususnya pendidikan tinggi.

\section{Kompetensi Digital sebagai Strategi Peningkatan Pendidikan di Era Modern}

Kompetensi digital menjadi sebuah keharusan dan bukan lagi sekadar support. Keterampilan, pengalaman, dan pengetahuan pemanfaatan teknologi digital yang tergabung menjadi sebuah knowledge dan kompetensi menjadi penting untuk dikuasai penuh oleh para stakeholder pendidikan khususnya dalam naungan Sivitas Akademika pada perguruan tinggi.

Kompetensi digital menjadi sebuah strategi dalam mengatasi permasalahan yang ada. Peningkatan keterampilan dan kompetensi digital serta pemikiran komputasional membentuk domain kognitif mahasiswa yang bersumbangsih besar terhadap keberhasilan pendidikan yang dilakukan. Peningkatan kompetensi kepribadian dan profesionalisme dosen akan meningkat dengan penguasaan dan kompetensi digitla yang baik. Peningkatan terhadap proses dan pelayanan akademik dapat terjadi khususnya dengan fasilitas dan pemanfaatan teknologi yang baik oleh tenaga kependidikan. Pemanfaatan teknologi khususnya teknologi digital akan sangat maksimal dengan kompetensi digital yang baik yang harus dimiliki seluruh tenaga kependidikan dalam mendukung berbgai kegiatan akademik pada perguruan tinggi.

Tabel 2. Permasalahan Teknologi Digital vs Kompetensi Digital

\section{Permasalahan dalam Pemanfaatan Teknologi Digital}

Copy Paste file digital dalam mendukung tugas dan kebutuhan akademik lain tanpa melakukan edit dan pengembangan. Tidak membuat pengetauan baru dengan bahan informasi yang didaptkan melalui file digital

Tidak mencantumkan sumber pustaka dan referensi yang didapatkan dari dokumen digital orang lain melalui hasil pencarian di internet. Kurangnya pemahaman terhadap Hak Kekayaan Intelektual

Kurangnya pemahaman penggunaan keyword (kata kunci) dalam menggunakan search engine internet.

\section{Kompetensi Digital}

Knowledge Assembly

Etika Komputer, Hak

Atas Kekayaan

Intelektual

Internet Searching 


\begin{tabular}{|c|c|}
\hline $\begin{array}{l}\text { Ketidaktahuan dan kurangnya keinginan penggunaan alat bantu } \\
\text { yang ada pada website seperti Frequently Asked Question (FAQ), } \\
\text { alat terjemah bahasa, dan Contact Us }\end{array}$ & Content evaluation \\
\hline $\begin{array}{l}\text { Kurangnya pengetahuan sumber-sumber referensi, kajian, jurnal, } \\
\text { dan website yang kredibel, khususnya yang digunakan dalam } \\
\text { mendukung pembelajaran keagamaan Buddha. }\end{array}$ & Knowledge Assembly \\
\hline $\begin{array}{l}\text { Manajemen file yang kurang khususnya dalam penamaan file dan } \\
\text { folder, lokasi menyimpan file dan data, pemahaman karakteristik } \\
\text { media penyimpanan }\end{array}$ & Manajement Data \\
\hline $\begin{array}{l}\text { Belum dimilikinya kemampuan menjaga data dari virus, worm, } \\
\text { dan malware }\end{array}$ & Security Computer \\
\hline $\begin{array}{l}\text { Kurangnya pembiasaan, pemahaman dan keinginan melakukan } \\
\text { backup data }\end{array}$ & Backup Data \\
\hline \multicolumn{2}{|l|}{ Dosen } \\
\hline $\begin{array}{l}\text { Kurangnya pemahaman dalam menjaga data dan file, khususnya } \\
\text { dari virus, worm, dan malware }\end{array}$ & Security Computer \\
\hline $\begin{array}{l}\text { Kurangnya keinginan untuk berbagi pengetahuan dan } \\
\text { pengalaman melalui blog dan website (knowledge sharing) }\end{array}$ & $\begin{array}{l}\text { Knowledge Assembly, } \\
\text { Penciptaan dan } \\
\text { komunikasi informasi } \\
\text { digital }\end{array}$ \\
\hline $\begin{array}{l}\text { Budaya copy paste tanpa mencantumkan sumber, dan rendahnya } \\
\text { analisis serta keinginan membuat pengetahuan baru hasil } \\
\text { interaksi dengan teknologi digital }\end{array}$ & Etika Komputer \\
\hline $\begin{array}{l}\text { Kurangnya keterlibatan dosen dalam forum diskusi ilmiah } \\
\text { khususnya melalui media online }\end{array}$ & $\begin{array}{l}\text { Knowledge Assembly, } \\
\text { Penciptaan dan } \\
\text { komunikasi informasi } \\
\text { digital }\end{array}$ \\
\hline $\begin{array}{l}\text { Rendahnya akses terhadap website jurnal ilmiah dan jurnal } \\
\text { Buddhis, khususnya dengan akses dengan pemanfaatan media } \\
\text { internet }\end{array}$ & Knowledge Assembly \\
\hline $\begin{array}{l}\text { Belum dapat memperbaiki berbagai permasalahan komputer, } \\
\text { khususnya pada laptop pribadi dan Personal Computer (PC) } \\
\text { Kantor }\end{array}$ & Maintenance Computer \\
\hline $\begin{array}{l}\text { Ketidaktahuan dan kurangnya keinginan penggunaan alat bantu } \\
\text { yang ada pada website seperti Frequently Asked Question (FAQ), } \\
\text { alat terjemah bahasa, dan Contact Us. Kurangnya pemahaman } \\
\text { penggunaan website tertentu untuk mendukung tugas dan fungsi } \\
\text { sebagai dosen }\end{array}$ & Content evaluation \\
\hline \multicolumn{2}{|l|}{ Tenaga Kependidikan } \\
\hline $\begin{array}{l}\text { Kurangnya pemahaman terhadap Karakteristik Website dan } \\
\text { fungsi link pada website }\end{array}$ & Hypertextual Navigation \\
\hline $\begin{array}{l}\text { Kurangnya pemahaman terhadap kapisitas file, data, dan } \\
\text { bandwith. Rendahnya pengetahuan terhadap berbagai software } \\
\text { yang berfungsi untuk mengatasi berbagai permasalahan kapaistas } \\
\text { file, data, dan bandwith }\end{array}$ & Hypertextual Navigation \\
\hline $\begin{array}{l}\text { Rendahnya keinginan untuk mempelajari dan mencari informasi } \\
\text { lebih dalam melalui website dan interntet (surfing) }\end{array}$ & Internet Searching \\
\hline $\begin{array}{l}\text { Kurangnya keterampilan untuk menjaga komputer dan laptop } \\
\text { agar tetap berfungsi maksimal tanpa kendala. Kurangnya } \\
\text { pemahaman untuk menjaga data dan file digital }\end{array}$ & $\begin{array}{l}\text { Security Computer, } \\
\text { Maintenance Computer }\end{array}$ \\
\hline $\begin{array}{l}\text { Ketidaktahuan dan kurangnya keinginan penggunaan alat bantu } \\
\text { yang ada pada website seperti Frequently Asked Question (FAQ), } \\
\text { alat terjemah bahasa, dan Contact Us. }\end{array}$ & Content evaluation \\
\hline
\end{tabular}


Kurangnya pemahaman penggunaan website dalam mengatasi permasalahan file dan data berkaitan dengan tugas dan fungsi tenaga kependidikan

\section{Strategi Inplementasi Kompetensi Digital Pada Perguruan Tinggi}

Penjabaran permasalahan dalam pemanfaatan teknologi digital pada STABN Sriwijaya memberikan gambaran keterampilan digital mahasiswa, dosen, dan tenaga kependidikan. Untuk selanjutnya permasalahan yang ada digunakan untuk menganalisis berbagai keterampilan dan kompetensi digital yang harus dikuasai dan dibutuhkan dalam mendukung berbgai kegiatan akademik dan juga dalam pelaksanaan tugas oleh tenaga kependidikan.

Tabel 3. Strategi Implementasi Kompetensi Digital pada Perguruan Tinggi

\begin{tabular}{|l|l|}
\hline \multicolumn{1}{|c|}{ Kompetensi Digital Mahasiswa } & \multicolumn{1}{|c|}{ Strategi Implementasi } \\
\hline Knowledge Assembly & $\begin{array}{l}\text { Pembelajaran di dalam kelas, Model Discovery } \\
\text { Learning, Model Problem Based Learning }\end{array}$ \\
\hline $\begin{array}{l}\text { Etika Komputer, Hak Atas Kekayaan } \\
\text { Intelektual }\end{array}$ & $\begin{array}{l}\text { Pembelajaran di dalam kelas, Seminar, } \\
\text { Workshop }\end{array}$ \\
\hline Internet Searching & $\begin{array}{l}\text { Pembelajaran di dalam kelas, Model Student } \\
\text { Centered learning, }\end{array}$ \\
\hline Content evaluation & $\begin{array}{l}\text { Pembelajaran di dalam kelas, Strategi Case } \\
\text { Based Learning, }\end{array}$ \\
\hline Knowledge Assembly & $\begin{array}{l}\text { Pembelajaran di dalam kelas, Strategi Learning } \\
\text { bu Exploring }\end{array}$ \\
\hline Manajement Data & $\begin{array}{l}\text { Pembelajaran di dalam kelas, knowledge } \\
\text { sharing, Seminar, pelatihan }\end{array}$ \\
\hline Security Computer & knowledge sharing, Seminar, pelatihan \\
\hline Backup Data & Pembelajaran, di dalam kelas, pelatihan \\
\hline \multicolumn{1}{|c|}{ Kompetensi Digital Dosen } & Strategi Implementasi \\
\hline Security Computer & Seminar, Pelatihan, Knowledge Sharing \\
\hline $\begin{array}{l}\text { Knowledge Assembly, Penciptaan dan } \\
\text { komunikasi informasi digital }\end{array}$ & Seminar, Pelatihan, Knowledge Sharing \\
\hline Etika Komputer & Seminar, Sosialisasi \\
\hline Knowledge Assembly & $\begin{array}{l}\text { Focus Group Discussion, Seminar, Pelatihan, } \\
\text { Knowledge Sharing }\end{array}$ \\
\hline Maintenance Computer & Knowledge Sahring, Pelatihan \\
\hline Content evaluation & Pelatihan, Knowledge Sharing \\
\hline Hypertextual Navigation & Pelatihan, Focus Group Discussion, \\
\hline Internet Searching & Pelatihan, Knowledge Sharing \\
\hline Compurity Computer, Maintenance & Seminar, Pelatihan, Workshop \\
\hline Content evaluation & Pelatihan, Knowledge Sharing \\
\hline Internet Searching & Knowledge Sharing, Pelatihan \\
\hline Komaring
\end{tabular}


Kompetensi digital sebagai strategi peningkatan proses pendidikan pada perguruan tinggi tidak langsung memberikan kontribusi maksimal terhadap proses pendidikan yang dilakukan, tentunya membutuhkan strategi implementasi yang direncanakan dengan langkah-langkah strategis melalui berbagai sub bidang yang sesuai.

Kompetensi digital mahasiswa menitikberatkan strategi implementasi melalui pembelajaran dengan berbagai model dan pendekatan. Knowledge Assembly merupakan kompetensi sebagai suatu kemampuan untuk menyusun pengetahuan, membangun suatu kumpulan informasi yang diperoleh dari berbagai sumber, dan kemampuan untuk mengumpulkan dan mengevaluasi fakta dan opini dengan baik. Secara nyata kompetensi Knowledge Assembly dapat menjadi stategi dalam mengatasi permasalahan yang ada pada STABN Sriwijaya yang merupakan Perguruang Tinggi Keagamaan Buddha dalam memberikan dukungan terhadap proses mendapatkan informasi akademik berkaitan dengan kajian-kajian Buddhis, sumber-sumber referensi pendidikan Buddhis, jurnal Buddhis, dan websitewebsite peyedia informasi yang berguna bagi pendidikan keagamaan Buddha.

Urgensi Knowledge Assembly membutuhkan strategi implementasi besar dalam pembelajaran. Pembelajaran pada perguruan tinggi diharapkan menerapkan berbagai model, pendekatan, dan strategi seperti model Discovery Learning dan model Problem Based Learning yang memungkinkan terciptnya kompetensi digital mahasiswa sehingga mampu keluar dari berbagai permasalah yang ada. Berbeda dengan mahasiswa, kompetensi digital pada dosen dan tenaga kependidikan dapat dilakukan melalui kegiatan seminar, pelatihan, workshop, dan juga berbagai kegiatan knowledge sharing yang memungkinkan terciptanya berbagai pengatahuan dalam membentuk kompetensi digital. 


\section{KESIMPULAN}

Kompetensi digital mejadi solusi dan strategi dalam mengatasi berbagai permasalahan yang ada pada perguruan tinggi khususnya dalam menghadapi era pendidikan modern. Kompetensi Knowledge Assembly, Etika Komputer, Internet Searching, Content Evaluation, Knowledge Assembly, Manajement Data, Security Computer, Backup Data, Hypertextual Navigation, dan Maintenance Computer merupakan sebuah keharusan yang menjadi penting terhadap operasinal pendidikan. Mahasiswa, dosen, dan tenaga kependidikan diharapakkan mencapai dan memiliki kompetensi digital untuk keluar dari permasalahan yang ada, lebih lanjut akan memberikan kontribusi besar terhadap tercapainya tujuan pendidikan yang telah ditetapkan.

Impelemntasi kompetensi digital membutuhkan langkah-langkah strategis dan perencanaan yang baik sehinga dapat terwujud dan memberikan kontribus maksimal terhadap peningkatan pendidikan di era modern. Model, strategi, dan pendekatan pembelajaran salah satu bentuk strategi impelemtasi kompetensi digital pada mahasiswa. Sedangkan untuk dosen dan tenaga kependidikan, langkah strategis implementasi kompetensi digital dapat dilakukan melalui seminar, pelatihan, Focus Group Discussion (FGD), dan berbagai kegiatan knowledge sharing. 


\section{E. Referensi}

Davis, Charles H, Shaw, Debora. 2011. Introduction to Information Science and Technology. Information Today: new Jersey.

Frydenberg, M., \& Andone, D. 2011. Learning 21 st Century Skills.

Gilster, Paul. 1997. Digital Literacy. New York: Wiley.

Indrajit, Richardus Eko. 2011. Peranan Teknologi Informasi pada Perguruan Tinggi (paradigma, konsep, strategi implementasi). Aptikom.

Indrajit dan Djokopranoto. Manajemen Perguruan Tinggi Moderen. n.p. n.d. Print.

Undang-undang Republik Indonesia Nomor 12 Tahun 2012 Tentang Pendidikan Tinggi. 